blood and tissues of juvenile Coho salmon. $J$. Fish Res. Bd. Can. 30: 395-400.

Sambasiva Rao, K.R., K.S. Prasada Rao, I.K. Ahaned Sahib and K.V. Raman Rao 1985. Combined action of carbaryl and phenthoate on a fresh water fish. C. puncatus (Bloch.).

Ecotoxicol. Environ. Saf. 10: 209-217.

Subramaniam, M.A., M.S. Hameed and G.
Varadaraj 1988. Haematological changes in the fish Macrones keletius (Gurther) after exposure to the tannery effluent. The Indian Zoologist 12: 71-74.

Waluga, D. 1966. Phenol effects on the anatomical and histopathological changes in bream (Abramis brama L.). Acta. Hydrobiol. $8: 55-78$.

\title{
On Some Diatoms from Upper Mustang Trans-Himalaya Region, Nepal
}

\author{
B.R. Subba ${ }^{1}$, M.R. Pandey ${ }^{2}$, K.P. Limbu ${ }^{1}$ and S.K. Rai ${ }^{3 *}$ \\ ${ }^{1}$ Department of Zoology, P.G. Campus, T.U., Biratnagar \\ ${ }^{2}$ National Trust for Nature Conservation, Annapurna Conservation Area Project, Unit Conservation Office, \\ Jomsom. \\ ${ }^{3}$ Department of Botany, P.G. Campus, T.U., Biratnagar \\ "E-mail: shivarai2003@yahoo.com
}

Received: 07.11.2009, Accepted: 25.12.2009

Key words: Algae, Diatoms, Upper Mustang Trans-Himalaya, Nepal

A total 19 diatom taxa viz. Achnanthes flexella (Kütz.) Brun., Amphora libyca Ehr., Cymatopleura solea (Bréb.) W. Smith, Cymbella affinis Kütz., Cymbella cistula (Ehr.) Kirchn., Cymbella helvetica Kütz., Cymbella radiosa Reichelt, Denticula elegans Kütz., Diatoma hiemale (Lyngb.) Heib., Gomphonema clavatum Ehr., Hannaea arcus var. arcus (Ehr.) Patrick in Patrick \& Reimer, Navicula cuspidata Kütz., Neidium affine (Ehr.) Pfitzer, Pinnularia viridis (Nitzsch) Ehr., Rhopalodia gibba (Ehr.) O. Müller, Staurosirella leptostauron (Ehr.) Williams \& Round, Surirella linearis W. Smith, Surirella spiralis Bréb. and Synedra ulna (Nitz.) Ehr. under 15 genera were recorded from Upper Mustang Trans-Himalaya region, Nepal (Figs 1-22). Among these, Cymbella, Diatoma, Hannaea and
Pinnularia spp. were the most abundant genera whereas genera like Amphora, Gomphonema and Neidium were rare.

Upper Mustang (28 $47^{\prime} 39^{\prime \prime}$ to $29^{\circ} 19^{\prime} 54^{\prime \prime} \mathrm{N} \& 83^{\circ} 28^{\prime} 55^{\prime \prime}$ to $84^{\circ} 15^{\prime} 16^{\prime \prime} \mathrm{E}$ ) occupies almost half of the area (ca 2567 $\mathrm{km}^{2}$ ) of northorn Mustang district in the Trans Himalayan region of Nepal, north to the Himalayan range (Map 1). It is bordered by Tibet of China, Dolpa district, Manang district and southern mountains in the north, west, east and south respectively. There are seven VDCs viz. Chhoser, Chhonup, Lo Manthang, Tsarang, Surkhang, Ghami and Chhuksang in which several freshwater streams and rivers flow originating from Himalayas and high mountains. The rocks are mainly metamorphic type comprising conglomerates, granite etc. and most of the observed rocks across the Kali Gandaki 


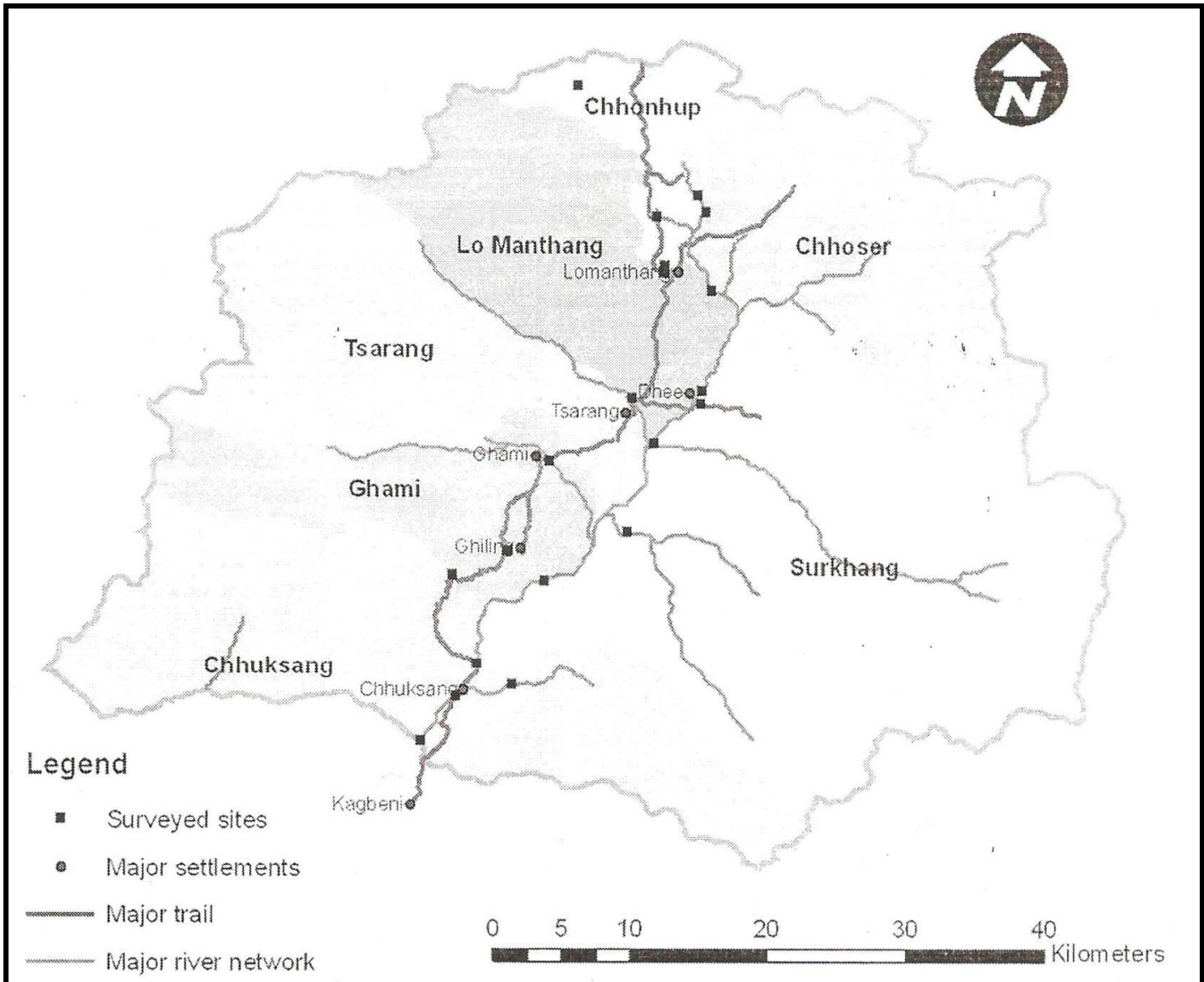

Map 1. Upper Mustang showing surveyed route and sample collection points.

river were found having fossils especially of marine mollusks which are remarkable natural resources restricted to Upper Mustang only. This region lies in the rain shadow and has very low precipitation. The temperature recorded from $8 \mathrm{pm}$ to $5 \mathrm{pm}$ during field survey in June ranged from $15^{\circ} \mathrm{C}$ to $24.8^{\circ} \mathrm{C}$ and humidity was between 38 and 41 .

The present diatom samples were collected by Dr. B.R. Subba during the expedition on "An inventory of aquatic biodiversity of Upper Mustang, Nepal" in the period of 12-25 June, 2005 (Map 1). Collection were made from 19 fresh water streams starting from Bhalle Khola $\left(29^{\circ} 18^{\prime} 08.5^{\prime \prime} \mathrm{N} \& 083^{\circ} 5.3^{\prime} 41.8^{\prime \prime} \mathrm{E}, 4688 \mathrm{msl}\right)$ to Sangta Khola $\left(28^{\circ} 52^{\prime} 41.6^{\prime \prime} \mathrm{N}\right.$ \& 083 47'31.1"E, $2888 \mathrm{msl}$ ) and from one pond Chhyo Pema $\left(29^{\circ} 13^{\prime} 10.5^{\prime \prime} \mathrm{N} \&\right.$ $083^{\circ} 58^{\prime} 44.9^{\prime \prime} \mathrm{E}, 3839 \mathrm{msl}$ ). Between these, other diatom localities were Nhijung Dhokpo (2910'53.4"N \& 8357'5.8"E, 3825 $\mathrm{msl})$, Lo Manthang Khola $\left(29^{\circ} 11^{\prime} 8.0^{\prime \prime} \mathrm{N} \&\right.$ $83^{\circ} 57^{\prime} 7.5^{\prime \prime} \mathrm{E}, \quad 3769 \quad \mathrm{msl}$, Chharang/Mharchung $\left(29^{\circ} 10^{\prime} 12.5^{\prime \prime} \mathrm{N} \quad\right.$ \& 8358'59.6"E, $3627 \mathrm{msl}$ ), Kimling Khola $\left(29^{\circ} 13^{\prime} 0.1^{\prime \prime} \mathrm{N}\right.$ \& 8356'48.9" E, $\left.3997 \mathrm{msl}\right)$, Tsarang Khola- Ghuyung Dhokpo (29 $\left.06^{\prime} 03.2^{\prime \prime} \mathrm{N} \& 83^{\circ} 55^{\prime} 50.9^{\prime \prime} \mathrm{E}, 3463 \mathrm{msl}\right)$, 
Our Nature (2009) 7
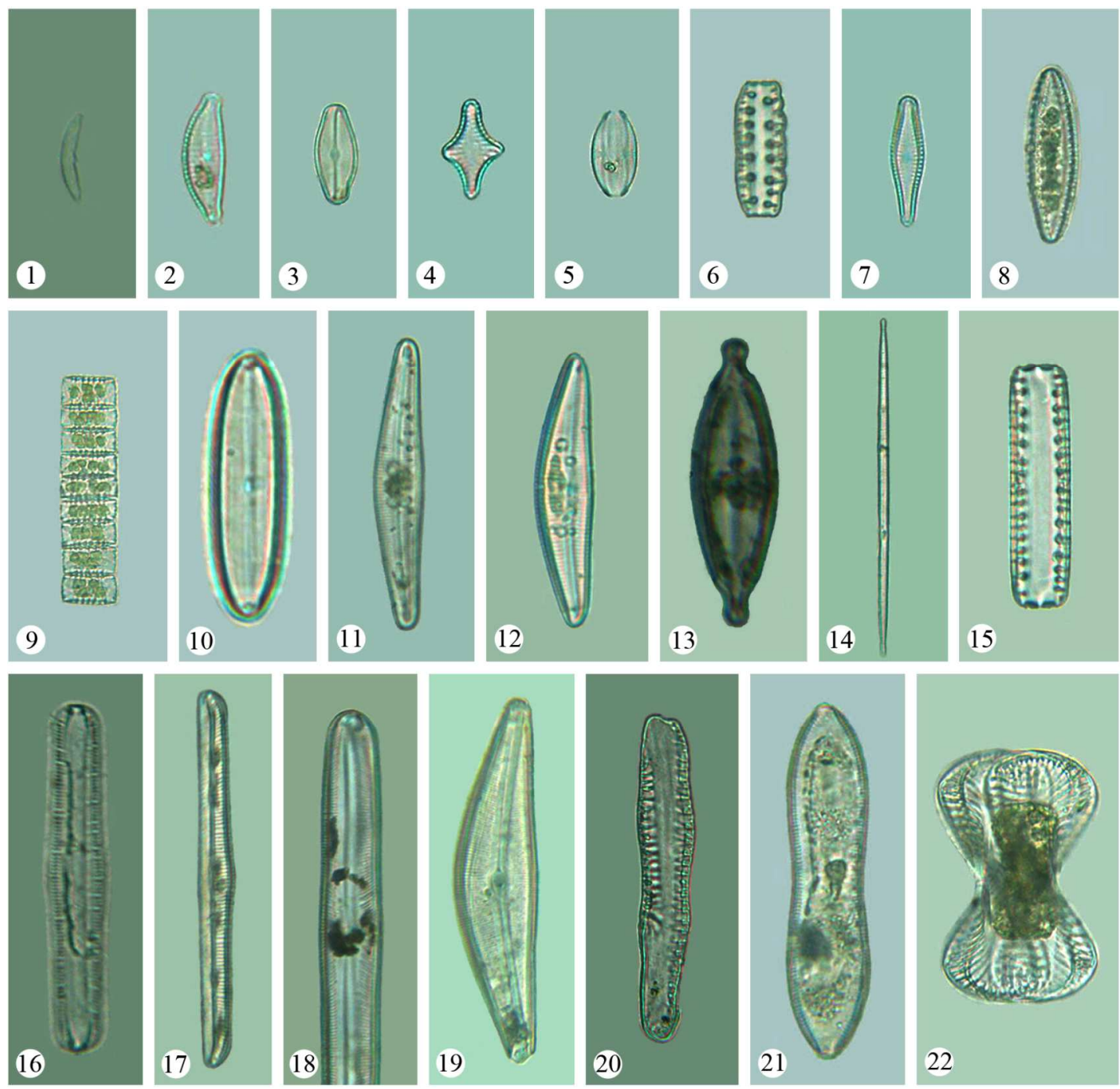

Figures: 1. Hannaea arcus var. arcus (Ehr.) Patrick in Patrick \& Reimer, 2. Cymbella affinis Kütz., 3. Achnanthes flexella (Kütz.) Brun., 4. Staurosirella leptostauron (Ehr.) Williams \& Round, 5. Amphora libyca Ehr., 6. Denticula elegans Kütz., 7. Gomphonema clavatum Ehr., 8. Surirella linearis W. Smith, 9. Diatoma hiemale (Lyngb.) Heib., 10. Neidium affine (Ehr.) Pfitzer, 11. Cymbella helvetica Kütz., 12. Cymbella radiosa Reichelt, 13. Navicula cuspidata Kütz., 14. Synedra ulna (Nitz.) Ehr., 15. Denticula elegans Kütz., 16-17. Rhopalodia gibba (Ehr.) O. Müller, 18. Pinnularia viridis (Nitzsch) Ehr., 19. Cymbella cistula (Ehr.) Kirchn., 20. Denticula elegans Kütz., 21. Cymatopleura solea (Bréb.) W. Smith, 22. Surirella spiralis Bréb.

Dhey Khola $\left(29^{\circ} 04^{\prime} 17.0^{\prime \prime} \mathrm{N} \& 83^{\circ} 56^{\prime} 43.7^{\prime \prime} \mathrm{E}\right.$ $3315 \mathrm{msl})$, Tangya Khola $\left(29^{\circ} 00^{\prime} 50.1^{\prime \prime} \mathrm{N} \&\right.$ $\left.83^{\circ} 55^{\prime} 41.4^{\prime \prime} \mathrm{E}, 3235 \mathrm{msl}\right)$, Dhee Khola $\left(29^{\circ} 06^{\prime} 19.8^{\prime \prime} \mathrm{N} \& 8^{\circ} 58^{\prime} 36.4^{\prime \prime} \mathrm{E}, 3384 \mathrm{msl}\right)$,
Yara Khola $\left(29^{\circ} 05^{\prime} 50.2^{\prime \prime} \mathrm{N} \& 83^{\circ} 58^{\prime} 34.2^{\prime \prime} \mathrm{E}\right.$, $3414 \mathrm{msl})$, Garphu Khola $\left(29^{\circ} 13^{\prime} 48.8^{\prime \prime} \mathrm{N} \&\right.$ 835'ㄷ'ㄹ, $3891 \mathrm{msl}$ ), Ghami Khola $\left(29^{\circ} 03^{\prime} 35.2^{\prime \prime} \mathrm{N} \& 83^{\circ} 52^{\prime} 35.2^{\prime \prime} \mathrm{E}, 3475 \mathrm{msl}\right)$, 


\section{Our Nature (2009) 7}

Kali Gandaki river near Ghiling

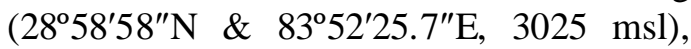
Tamagaun Khola $\left(29^{\circ} 00^{\prime} 7.4^{\prime \prime} \mathrm{N} \quad \&\right.$ $83^{\circ} 50^{\prime} 55.5^{\prime \prime} \mathrm{E}, 3604 \mathrm{msl}$ ), Yamda Khola (28 59'11.1"N \& 8348'45.5" E, $3889 \mathrm{msl}$ ) and Narsingh Khola $\left(28^{\circ} 54^{\prime} 53.3^{\prime \prime} \mathrm{N} \&\right.$ 8351'7.7"E, $3089 \mathrm{msl}$ ) (Locality photographs).

Epiphytic forms were squeezed from root and leaves of submerged macrophytes, epilithic forms were scrubbed from pebble surfaces using toothbrushes and planktonic forms were trapped using phytoplankton net (mesh size-10u). Diatom samples were preserved in $4 \%$ (final concentrateon) formalin. In laboratory, samples were centrifuged, washed with hot saturated solution of chromic acid $\left(\mathrm{K}_{2} \mathrm{Cr}_{2} \mathrm{O}_{7}\right.$ in conc. $\mathrm{H}_{2} \mathrm{SO}_{4}$ ) and mounted by euparol. The slides thus prepared were observed and microphotographs of the frustules were taken using Carl Zeiss Axioster plus Microscope and Canon digital camera. The diatoms were identified following monographs of Tiffany and Britton (1952), Hustedt (1961-1966), Prowse (1962), Metzeltin and Lange-Bertalot (1998), Gandhi (1999), You et al. (2009) and ADIAC database. Slides have been deposited at the Department of Botany, P.G. Campus, Biratnagar.

Himalayan diatoms of Nepal has been studied by Hirano (1955, 1963, 1969, 1984), Suxena and Venkateswarlu (1968), Suxena et al. (1972), Jüttner et al. (1996, 2000, 2003, 2004) and Yoshimura et al. (1997, 2000, 2006). Though, thousands of glacier lakes, icefed streams and ponds are still untouched phycologically. From Mustang, Hirano (1955) has reported few diatoms from Tukucha moor $(2600 \mathrm{msl})$ and tributaries of Kali Gandaki (2500 msl) but after that no other reports have been released from this area. Thus, in the present study, an attempt has made to explore high altitude diatoms from Nepal Himalayas.

\section{Acknowledgements}

We are thankful to Mr. Arup Rajauria, Member Secretary of KMTNC and Mr. Ganga Jang Thapa, National Project Coordinator of KMTNC-ACAP/UMBCP for financial assistance to carry out this study. Thanks also due to Mr. Madhu Chetri, National Program Manager of the same for his enthusiastic help and suggestions. We wise to thank Mr. Nawa Raj Chapagain, GIS officer of the KMTNCACAP/UMBCP for GIS map products and other supports.

\section{References}

ADIAC (Automatic Diatom Identification and Classification) funded by the European Marine Science and Technology (MAST) Programme. (ADIAC public image database)

Gandhi, H.P. 1999. Fresh water diatom of Cental Gujrat. B. Singh and M.P. Singh, Deharadun, India. $324 \mathrm{p}$.

Hirano, M. 1955. Fresh water algae. In Fauna and flora of Nepal Himalaya (Ed. H. Kihara). Fauna and Flora Research Society, Kyoto University, Kyoto, Japan. pp. 5-42.

Hirano, M. 1963. Fresh water algae from the Nepal Himalaya, collected by a member of the Japanese Climbing Expedition. Contr. Biol. Lab., Kyoto Univ., Japan. 16: 1-23.

Hirano, M. 1969. Fresh water algae from Langtang Himal, Nepal Himalaya. Contr. Biol. Lab., Kyoto Univ., Japan. 22: 1-42.

Hirano, M. 1984. Fresh water algae from East Nepal. Study reported of Baika Junior College 32: $197-$ 215.

Hustedt, F. 1961-1966. Die Kieselalgen Deutschlands, Österreichs und der Schweiz unter Berücksichtigung der übrigen Länder Europas sowie der angrenzenden Meeresgebiete, Part 3, Vol. VII. B. Singh and M.P. Singh, Dehradun, India. $816 \mathrm{p}$.

Jüttner, I., E. Reichardt and E.J. Cox 2004. Taxonomy and ecology of some new Gomphonema species 


\section{Our Nature (2009) 7}

common in Himalayan streams. Diatom Research 19(2): 235-264.

Jüttner, I., E.J. Cox and S.J. Ormerod 2000. New or poorly known diatoms from Himalayan streams. Diatom Research 15(2): 237-262.

Jüttner, I., H. Rothfritz and S.J. Ormerod 1996. Diatoms as indicators of river quality in the Nepalese Middle hills with consideration of the effects of habitat-specific sampling. Freshwater Biology 36: 475-486.

Jüttner, I., S. Sharma, B.M. Dahal, S.J. Ormerod, P.J. Chimonides and E.J. Cox 2003. Diatoms as indicators of stream quality in the Kathmandu valley and Middle hills of Nepal and India. Freshwater Biology 48: 2065-2084.

Metzeltin, D. and H. Lange-Bertalot 1998. Tropical diatoms of South America 1:700 predominately rarely known or new taxa representative of the neotropical flora. Vol.5. Lubrecht \& Cramer Ltd. NY, USA. 695p.

Prowse, G.A. 1962. Diatoms of Malayan fresh waters. The garden's bull., Singapore. 19(1): 1-105.

Suxena, M.R. and V. Venkateswarlu 1968. Algae of the Cho Oyu (E. Himalaya) Expedition-I. Bacillariophyceae. Hydrobiologia 32: 1-26.
Suxena, M.R., V. Venkateswarlu and V.S. Rao 1972 Algae of the Cho Oyo (E. Himalaya) Expedition-II. Bacillariophyceae-II. Nova Hedwigia 23(2-3): 415426.

Tiffany, L.H. and M.E. Britton 1952. The algae of Illinois. Hafner publishing Co., New York. 407p.

Yoshimura, Y., S. Kohshima and S. Ohtani 1997. A community of snow algae on a Himalayan glacier: Change of algal biomass and community structure with altitude. Arctic and Alpine Research 29(1): 126-137.

Yoshimura, Y., S. Kohshima, N. Takeuchi, K. Seko and K. Fujita 2006. Snow algae in a Himalayan ice core: New environmental markers for ice-core analyses and their correlation with summer mass balance. Annals of Glaciology 43: 148-153.

Yoshimura, Y., S. Kohshima, N. Takeuchi, K. Seko and K. Fujita 2000. Himalayan ice-core dating with snow algae. Journal of Glaciology 46(153): 335340.

You, Q., Y. Liu, Y. Wang and Q. Wang 2009. Taxonomy and distribution of diatoms in the genera Epithemia and Rhopalodia from the Xinjiang Uygur Autonomous Region, China. Nova Hedwigia 89(3-4): 397-430. 